\title{
Involvement of MAPK pathway in hypoxia-induced up-regulation of urokinase plasminogen activator receptor in a human prostatic cancer cell line, PC3MLN4
}

\author{
Kyung Hee Lee ${ }^{1,3}$, Eun Young Choi \\ Myung Soo Hyun ${ }^{1}$ and Jae-Ryong $\mathrm{Kim}^{2}$ \\ ${ }^{1}$ Department of Hemato-Oncology \\ ${ }^{2}$ Department of Biochemistry and \\ Molecular Biology \\ College of Medicine, Yeungnam University \\ Daegu 705-717, Korea \\ ${ }^{3}$ Corresponding author: Tel, 82-53-620-3845; \\ Fax, 82-53-654-8386; E-mail, Ikhee@med.yu.ac.kr
}

Accepted 5 January 2004

Abbreviations: DMSO, dimethyl sulfoxide; ECL, enhanced chemiluminescence; ECM, extracellular matrix; ERK, extracellular regulated kinase; HGF, hepatocyte growth factor; MAPK, mitogenactivated protein kinase; MTT, 3-(4,5-dimethylthiazol-2-yl)-2,5diphenyltetrazolium bromide; SDS, sodium dodecyl sulfate; UPA, urokinase plasminogen activator; UPAR, urokinase plasminogen activator receptor

\begin{abstract}
Clinical studies have shown that tumor hypoxia is associated with invasive growth and metastasis and may be an important prognostic factor adversely influencing survival in patients with tumors. To investigate the mechanisms involved in hypoxia-induced invasive growth and metastasis, hypoxia-mediated urokinase plasmalogen activator receptor (UPAR) expression, cellular invasiveness, and mitogen activated protein kinase (MAPK) activation were measured in a prostate cancer cell line, PC 3MLN4. The levels of UPAR expression and cellular invasiveness were increased in hypoxic cells. Hypoxia-induced cellular invasiveness was blocked by an anti-uPAR monoclonal antibody. Phosphorylations of ERK and p38 kinases were also more extensive in hypoxic cells than in normoxic cells. Hypoxia-induced uPAR up-regulation was inhibited by pre-treatments with a specific inhibitor of MEK, PD98059 and a specific inhibitor of p38 MAP kinase, SB203580. Cell growth also increased in hypoxic cells. From these results, hypoxia increased tumor cell invasion by up-regulating UPAR expression, which might be me-
\end{abstract}

diated through ERK and p38 kinase signaling pathways in PC3MLN4 prostate cancer cell line.

Keywords: HGF; hypoxia; MAPK; metastasis; UPAR

\section{Introduction}

Cancer invasion and metastasis result from a series of interdependent processes requiring, as an intermediate step, the active degradation of pericellular matrix and the disruption of basement membranes. Several proteolytic enzyme systems are reported to be involved in the metastatic spread of tumor cells, urokinase plasminogen activator (UPA)-urokinase plasminogen activator receptor (UPAR) pathway of which have been extensively studied (Dano et al., 1985; Blasi et al., 1987; Kwang et al., 2003). Hepatocyte growth factor (HGF) is an effector of the cells expressing the c-Met tyrosine kinase receptor (Birchmeier et al., 1993). The molecular mechanisms by which HGF/c-Met signaling promotes the invasive and metastatic phenotype are largely unknown, but probably involves the induction of proteases, which mediate the degradation of the ECM membrane (Body, 1989). Elevated levels of UPA have been shown to be associated with many malignant tumors including carcinomas of the prostate (Camiolo et al., 1981), colon (De bruin et al., 1988), lung (Markus et al., 1980) and breast (Sappino et al., 1987). The UPAR is a $55,000-60,000 \mathrm{Da}$ highly glycosylated protein, anchored to the plasma membrane. UPAR has been described in a number of different cell types including macrophage, endothelial cell, fibroblast, and several tumor cell lines. An autocrine and/or paracrine mechanism for secretion and binding of UPA to UPAR has been postulated (Ossowski et al., 1991). However, regardless of synthesis and activation of plasminogen and pro-urokinase by UPA, existing evidence shows that the ability of a tumor cell to invade and metastasis ultimately depends on the presence of UPAR. Consistent with these results, a number of reports well document the overexpression of UPAR in malignant tumors such as breast, ovary, lung, and pancreatic cancers (Ossowsky, 1988; Cantero et al., 1997).

Hypoxia has been known to be involved in many pathological processes including tumor formation, where it has been associated with resistance to radiotherapy and malignant progression. Hypoxia may 
also play an important roles in promoting tumor metastasis and invasion to the extracellular matrix (Brizel DM et al., 1996; Nordsmark et al., 1996). Exposure of immortalized human placental trophoblasts to hypoxia $\left(\begin{array}{lll}1 \% & O_{2}\end{array}\right)$ results in an increased invasion through the extracellular matrix (ECM) with elevated expression of UPA among with paralleled increases in cell surface-associated UPAR activity (Graham et al., 1998).

Mitogen-activated protein (MAP) kinases have been proposed to be an important signaling component linking extracellular stimuli to cellular response. MAP kinases can be activated by various external stimuli such as growth factors, hormones acting via G-protein coupled receptors, and physical stresses (Cobb and Goldsmith, 1995). Hypoxia has also been shown to stimulate extracellular regulated kinase (ERK) and p38 MAP kinase in different cell types (Seko et al., 1996; Seko et al., 1997).

In the light of the above consideration, we have investigated whether hypoxia increases in the expression of UPAR in an invasive human prostate cancer cell and whether MAP kinase signaling is involved in hypoxia-induced uPAR up-regulation. Knowledge gained from this study may provide a therapeutic basis for interfering with metastases produced by hormonerefractory human prostate cancers $(\mathrm{CaP})$ by downregulating UPAR-mediated proteolysis.

\section{Materials and Methods}

\section{Materials}

A human prostate cancer cell line, PC3MLN4, selected after 4 cycles of lymph node metastasis was kindly gifted from Dr. I. J. Fidler (University of Texas, Houston, TX). A mouse monoclonal antibody (3936) against UPAR with ability to block binding of UPA to UPAR was purchased from the American Diagnostica (Greenwich, CT). A uPAR cDNA probe, cloned in a pBC12B1 plasmid vector, was kindly donated by Dr. R. Radinsky (University of Texas, Houston, TX).

\section{Cell culture and treatment}

Cells were grown in a RPMI 1640 supplemented with $10 \%$ fetal bovine serum (FBS), $1 \mathrm{mM}$ sodium pyruvate, $0.1 \mathrm{mM}$ nonessential amino acids, $2 \mathrm{mM} \mathrm{L-}$ glutamine, two-fold vitamin solution, and $50 \mathrm{U} / \mathrm{ml}$ penicillin/streptomycin (Life technologies Inc., Grand Island, $\mathrm{NY}$ ) at $37^{\circ} \mathrm{C}$ in an incubator with $5 \% \mathrm{CO}_{2}$ and $95 \%$ humidified air. Unless otherwise noted, cells were subcultured at $70-80 \%$ confluence. For the treatment of hypoxia, cells were incubated in an airtight chamber, which was flushed with a mixed gas containing $5 \% \quad \mathrm{CO}_{2}$ and $95 \% \quad \mathrm{~N}_{2}$ for up to $24 \mathrm{~h}$ at $37^{\circ} \mathrm{C}$. Under these conditions, oxygen concentration in media is equilibrated within $30 \mathrm{~min}$ and remains at approximately $1 \%$ throughout the incubation period. For measurement of ERK and p38 activations in hypoxia, PC3M-LN4 cells were seeded on six-well plates $\left(1 \times 10^{6}\right.$ cells/well) and incubated at $37^{\circ} \mathrm{C}$ in a $5 \% \mathrm{CO}_{2}$ incubator for $24 \mathrm{~h}$. Following serum-starvation for $48 \mathrm{~h}$, the cells were exposed to hypoxic or normoxic condition for $0,5,10,20$ and $30 \mathrm{~min}$. To detect the role of ERK and p38 MAP kinase in hypoxia-induced UPAR up-regulation, PD 98059 (10 $\mathrm{mM})$, a specific inhibitor of MEK, and/or SB 203580 (1 $\mathrm{mM})$, a specific inhibitor of p38 MAP kinase, were added to serum- starved cells for $1 \mathrm{~h}$ prior to hypoxia exposure. Cells were also cultured under standard conditions in the presence of $100 \mathrm{mM}$ cobalt chloride (Sigma, St. Louis, MO).

\section{Flow cytometric analysis}

PC3MLN4 cells were detached by gently scraping in phosphate-buffered saline (PBS) containing $5 \mathrm{mM}$ EDTA. Single-cell suspensions were washed twice and resuspended at $1-3 \times 10^{6}$ cells $/ \mathrm{ml}$ in ice-cold PBS containing $2 \%$ FBS and $0.1 \%$ sodium azide. Cells were immunolabeled with a mouse monoclonal antibody against uPAR (3937, American Diagnostica, Greenwich, CT) at a final concentration of $10 \mathrm{mg} / \mathrm{ml}$ and incubated for $1 \mathrm{~h}$ at $4^{\circ} \mathrm{C}$. Cells were washed and resuspended in $\mathrm{PBS}+2 \% \mathrm{FBS}$. Goat $F\left(a^{\prime}\right) 2$ antimouse total immunoglobins conjugated with fluorescein isothiocyanate (FITC) were added to the cells to a final concentration of $4.0 \mathrm{mg} / \mathrm{ml}$. After fixation of the cells were then fixed with with $2 \%$ paraformaldehyde, the cell-bound FITC fluorescence was analyzed using an Elite flow cytometer (Coulter Corp., Hialeab, FL). The specific expression of UPAR was calculated as relative fluorescence units normalized with the control incubated without the primary antibody. We also cultured cells in the presence of $100 \mathrm{mmol} / \mathrm{l}$ cobalt chloride, an iron-chelating agent. Cobalt chloride has been reported to induce the conformation of heme proteins into the deoxy state, thereby initiating cellular hypoxic responses (Charles et al., 1998).

\section{Northern blot analysis}

Polyadenylated mRNA was extracted from $5 \times 10^{7}$ cells using the Fastrack mRNA isolation kit (Invitrogen Corp., San Diego, CA). mRNA was separated on a $1 \%$ denaturing formaldehyde agarose gel, transferred to Genescreen nylon membranes (Dupont Co., Boston, $\mathrm{MA}$ ), and cross-linked with $120,000 \mathrm{~mJ} / \mathrm{cm}^{2}$ using a UV crosslinker (Stratagene, La Jolla, CA). The membranes were washed 2-3 times at $60^{\circ} \mathrm{C}$ with $30 \mathrm{mM}$ $\mathrm{NaCl}, 3 \mathrm{mM}$ sodium citrate, $\mathrm{pH} 7.2$ and $0.1 \%(\mathrm{w} / \mathrm{v})$ 
SDS. The membranes were then hybridized with a ${ }^{32} \mathrm{P}$-labeled UPAR probe, which was radiolabeled using a random priming kit (Amersham corp., Arlington Heights, IL). After washing with $2 \times S S C, 0.5 \%$ SDS at room temperature and twice with $0.2 \times S S C$, $0.1 \%$ SDS at $42^{\circ} \mathrm{C}$, the membranes were exposed to $X$-ray films and $X$-ray films were then developed. Equal loading of mRNA was verified by reprobing the blots with a ${ }^{32} \mathrm{P}$-labeled tubulin probe.

\section{Western blot analysis}

Cells were harvested and lysed in a lysis buffer (20 $\mathrm{mM}$ Tris- $\mathrm{HCl}, \mathrm{pH} 7.5,137 \mathrm{mM} \mathrm{NaCl}, 10 \%$ Glycerol, $1 \%$ Triton $\mathrm{X}-100,1 \mathrm{mM} \mathrm{Na}_{3} \mathrm{VO}_{4}$, and $1 \mathrm{mM} \mathrm{PMSF}$ ). After centrifugation at $13,000 \mathrm{~g}$ for $5 \mathrm{~min}$, supernatants were transferred into new tubes and protein concentrations were determined with the BCA protein assay reagent (Pierce Biotechnology Inc., Rockford, IL) using bovine serum albumin as a standard. The proteins $(100 \mathrm{mg})$ were separated in a $10 \%$ SDSpolyacrylamide gel, transferred to a nitrocellulose membrane, and probed with anti-phospho ERK and anti-ERK antibodies (Cell Signaling Technology Inc., Beverly, MA). The blots were washed and incubated with anti-mouse or anti-rabbit $\lg G$ conjugated with horseradish peroxidase. Protein bands were visualized using an Enhanced Chemiluminescence kit (Amersham Bioscience., Boston., MA).

\section{3-(4,5-dimethylthiazol-2-yl)-2,5-diphenyltetrazolium bromide (MTT) assay}

Cells $\left(1 \times 10^{3}\right.$ cells/well) were seeded in a 96-well plate with a medium supplemented with $5 \%$ FBS and incubated for $24 \mathrm{~h}$. Cells were then serum-starved for $24 \mathrm{~h}$ and treated with 1\% FBS, 1\% FBS+ HGF (40 ng/ $\mathrm{ml}$ ), or $10 \%$ FBS for $72 \mathrm{~h}$ under hypoxia or normoxia. And then $50 \mathrm{ml}$ of MTT solution (2 $\mathrm{mg} / \mathrm{ml}$ in PBS) was added to the wells and further incubated for 3 $\mathrm{h}$ at $37^{\circ} \mathrm{C}$. The MTT solution was carefully removed through aspiration and the resulting formazan products converted by the viable cells were dissolved in $100 \mathrm{ml}$ of dimethyl sulfoxide. The absorbance at 570 $\mathrm{nm}$ was measured with a BioRad multiscan plate reader.

\section{Standard two chamber invasion assay}

Cells at $80 \%$ confluency were detached in PBS containing $5 \mathrm{mM}$ EDTA. Cells $\left(1 \times 10^{4}\right)$ and $\mathrm{UPAR} \mathrm{mAb}$ $3936(0,15,25$, or $50 \mathrm{mg} / \mathrm{ml})$ were placed at the top of a Matrigel migration chamber with 0.8 -micron pore (Fisher Scientific, Houston, TX). In the bottom chamber, media containing $5 \%$ FBS and HGF (0 or 40 $\mathrm{ng} / \mathrm{ml})$ with or without $\mathrm{mAb} 3936(0,15,25$, or 50 $\mathrm{mg} / \mathrm{ml}$ ) was added. Following incubation for $48 \mathrm{~h}$ under either normoxia or hypoxia, cells on the surface of the Matrigel-coated membrane were removed by scraping with a cotton swab. Remaining cells were then fixed and stained using a HEMA 3 stain set (Curtis Matheson Scientific, Houston, TX) according to the manufacturer's instruction. Cells migrated through the filter were quantified by counting cells in 10 fields at $200 x$ power.

\section{Densitometric quantitation}

The levels of UPAR mRNA and ERK and p38 phosphorylation were quantified using an LKB ultrascan $X L$ laser densitometer (Pharmacia LKB Biotechnology, Uppsala, Sweden) by averaging three separate measurements in the linear range of the film of the left, middle, and right areas of each band as well as the control.

\section{Results}

\section{Effect of exposure to hypoxia on cell surface levels of UPAR}

In order to investigate whether exposure to hypoxia increases the expression of UPAR in PC3MLN4 cells, the cells were incubated under either hypoxia or normoxia for $24 \mathrm{~h}$ and then the level of UPAR was measured using a flow cytometry. Hypoxia induced a 2.7 fold increase in the level of cell surface UPAR expression compared to normoxia. Cells were also treated with $100 \mathrm{mM}$ cobalt chloride for $24 \mathrm{~h}$ under normoxia. As expected, the level of UPAR was 1.6 fold higher in cells treated with cobalt chloride than in the untreated control cells (Figure 1).

To determine whether the hypoxia-induced upregulation of cell surface $U P A R$ reflected changes in the levels of uPAR mRNA, Northern blot analysis was performed. The level of UPAR mRNA in cells exposed to hypoxia was higher than that in cells under normoxia. Hypoxia-induced UPAR expression peaked at 3.9 folds at $3 \mathrm{~h}$ and maintained at 2 folds at $24 \mathrm{~h}$. Treatment with cobalt chloride also showed an increase in the level of UPAR mRNA (Figure 2).

\section{Effects of hypoxia on cellular invasion}

To test whether hypoxia-induced UPAR up-regulation is associated with an increase in cellular invasiveness, standard two-chamber invasion assay was applied. Hypoxic cells exhibited an invasion rate of 3 fold higher than normoxic cells. When we treated HGF under both conditions, HGF treated cells showed higher invasion than in the untreated cells. Furthermore, increased invasiveness of hypoxic cells was reduced in a dose-dependent manner by pretreatment with an anti-uPAR monoclonal antibody, 3936 (Figure 3). 

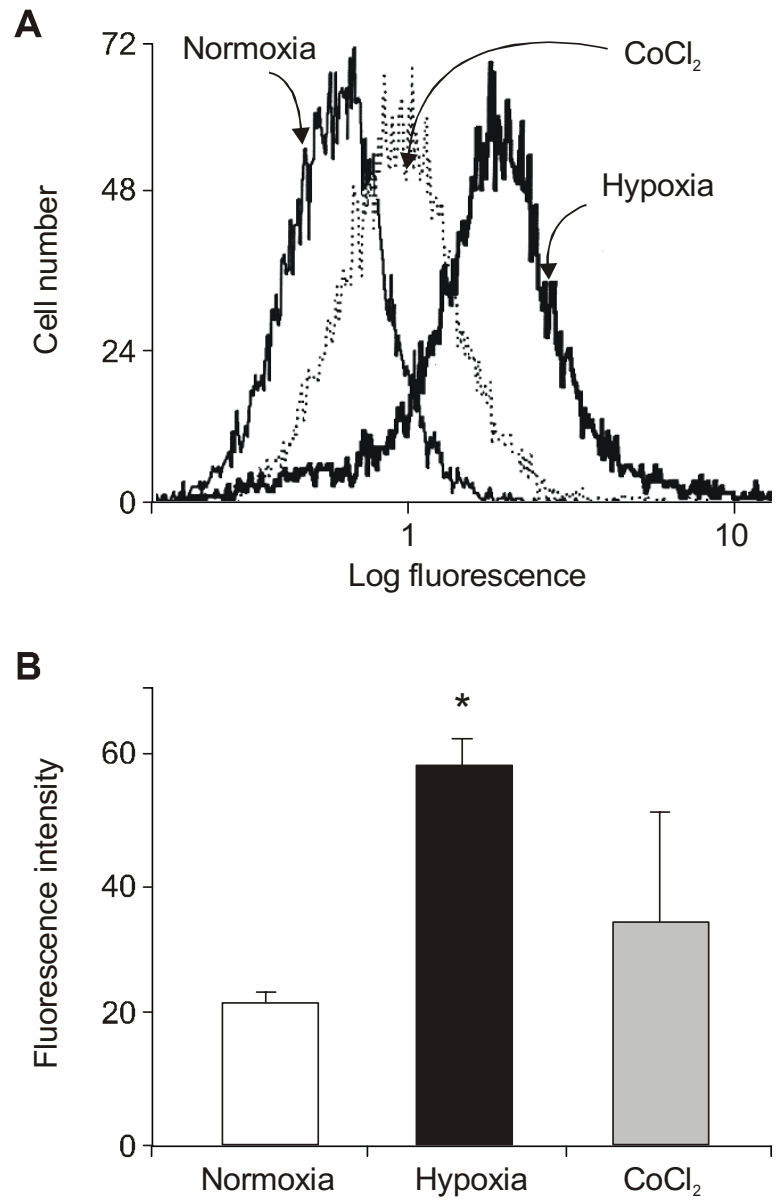

Figure 1. Effect of hypoxia and cobalt chloride on cell surface UPAR expression in PC3MLN4 prostate cancer cells. (A) Flow cytometric analysisy for cell surface UPAR in cells exposed to under either hypoxia or normoxia. (B) Mean fluorescence of cells. Values equal are mean $\pm S D$ of three independent experiments. (Statistical analysis: Student's t-test, ${ }^{*} P<0.05$; compared to the control)

\section{Hypoxia induces phosphorylations of ERK and p38 MAP kinases}

In an effort to evaluate the possibility that distinct signaling pathways are involved in hypoxia-induced UPAR up-regulation, the activations of ERK and p38 kinases were measured using Western blotting. Hypoxia-exposed cells showed a higher extent of ERK phosphorylation at $3 \mathrm{~min}$, but lower at 10 and $30 \mathrm{~min}$ than normoxic cells. Hypoxia-induced ERK phosphorylation occurred faster (Figure 4) and was peaked at 5 min. Hypoxia-induced phosphorylation of p38 MAP kinase was more extensive than that of normoxic cells. Phosphorylation of p38 MAP kinase in hypoxic cells was observed at $3 \mathrm{~min}$, highest at 20 min, and decreased to a basal level in 30 min (Figure 5).

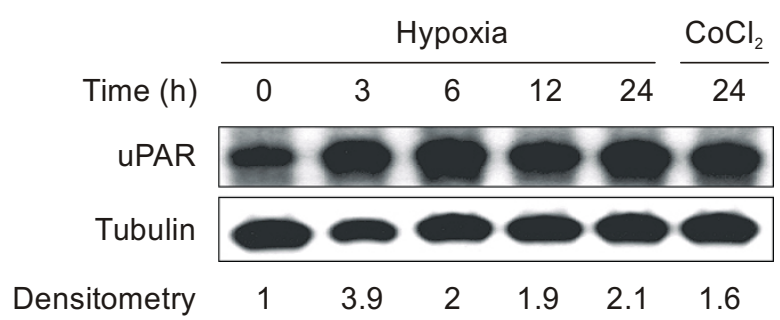

Figure 2. Northern blot analysis for UPAR in cells exposed to hypoxia or normoxia. mRNAs were purified from the cells, separated on a $1 \%$ formaldehyde agarose gel, and transferred to nylon membranes. The membranes were hybridized with a ${ }^{32} \mathrm{P}$-labeled UPAR probe. Equal loading of mRNAs were estimated with a ${ }^{32} \mathrm{P}$-labeled tubulin probe. The levels of UPAR expression were determined with densitometric analysis compared to the amounts of tubulin mRNA.

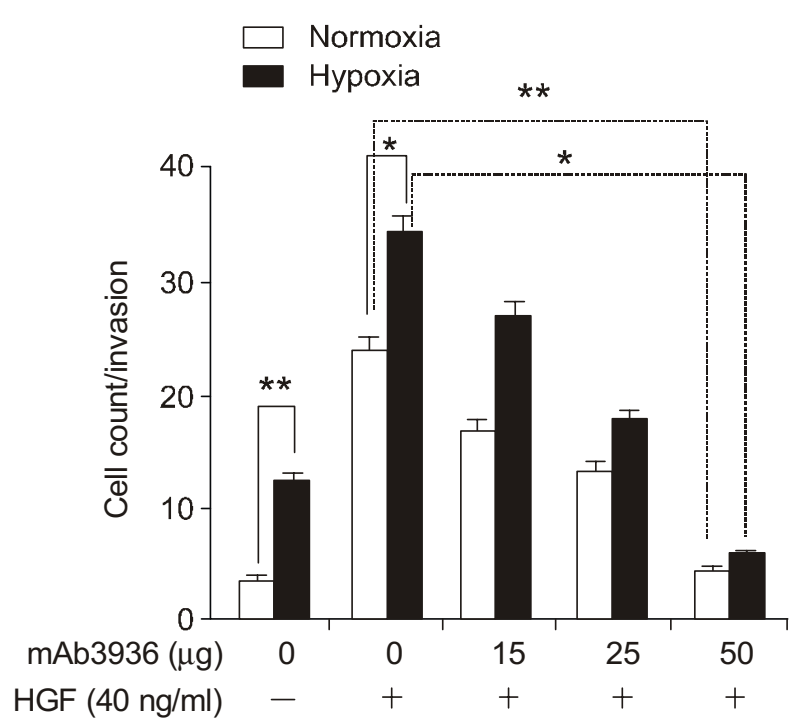

Figure 3. Effect of hypoxia on the in vitro invasiveness of PC3MLN4 cells. Cellular invasiveness under hypoxia or normoxia was measured by a standard two-chamber Matrigel invasion assay. Cells with or without an UPAR antibody ( $\mathrm{mAb} 3936$ ) were placed in the top of Matrigel-coated filter and media+5\% FBS supplemented with or without HGF and mAb 3936 was added to the bottom chamber. After incubation for $48 \mathrm{~h}$, cells migrated through the filter were quantified by counting 10 fields at $200 \mathrm{X}$ power. Values equal the mean $\pm S D$ of three independent experiments. (Statistical analysis: Student's t-test, ${ }^{*} P<0.05 ;{ }^{*} P<0.01$ compared to the control)

\section{Activations of ERK and p38 MAP kinase are necessary for hypoxia-induced UPAR up-regulation}

To test whether activation of ERK and p38 MAP is involved in the hypoxia-induced UPAR up-regulation, cells were pretreated with PD98059 or SB203580 and the UPAR level was measured by Western blotting. Hypoxia-induced UPAR up-regulation was reduced to a basal level by prior treatments of cells with PD98059 and SB203580 (Figure 6A and 6B). These 
A

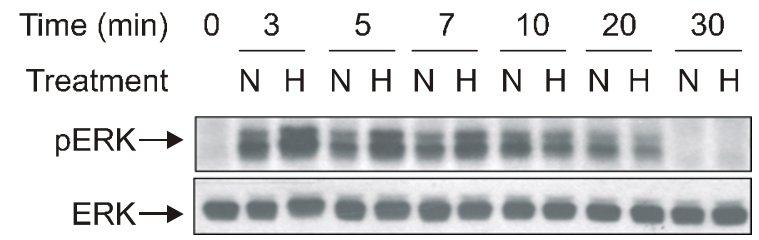

B

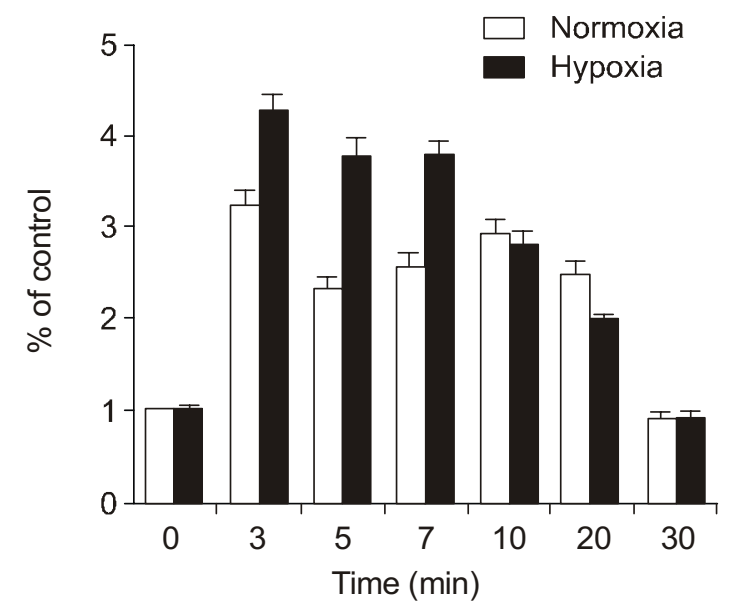

Figure 4. Effect of hypoxia on phosphorylation of ERK activations. Cells were incubated for $48 \mathrm{~h}$ in a serum-free medium and exposed to hypoxia or normoxia for the indicated times. Cell lysates were prepared and proteins were resolved in a 10\% SDS-polyacrylamide gel under reducing condition. ERK activations were analyzed through western blotting using phospho-ERK antibodies. Data shows a representative figure from three independent experiments and values equal the mean $\pm S E$.

results suggest that hypoxia-induced UPAR up-regulation is mediated by ERK and p38 kinase pathways.

\section{Anchorage-dependent cell growth assay}

Since activation of hypoxia-induced MAPKs was known to play an important role in cell proliferation (Das et al., 2001), we measured the cell growth between hypoxic and normoxic cells using an MTT assay. Hypoxia-exposed cells showed more than a $50 \%$ increment of cell growth compared to the normoxic cells (Figure 7).

\section{Discussion}

Tumor progression is a complex multi-step process by which a number of initiation factors promote the transformation of cells into their malignant phenotype. Once the malignant cellular phenotype is acquired, the process of tumor invasion continues to take place under the influence of a different group of progression factors.
A

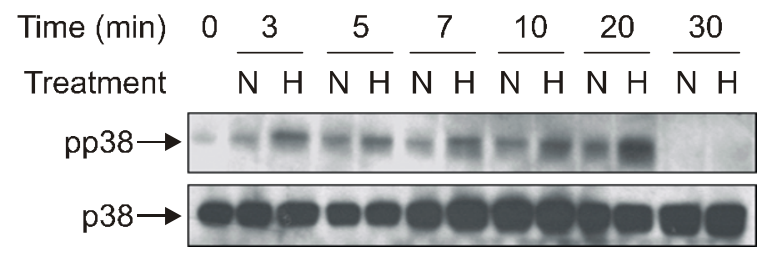

B

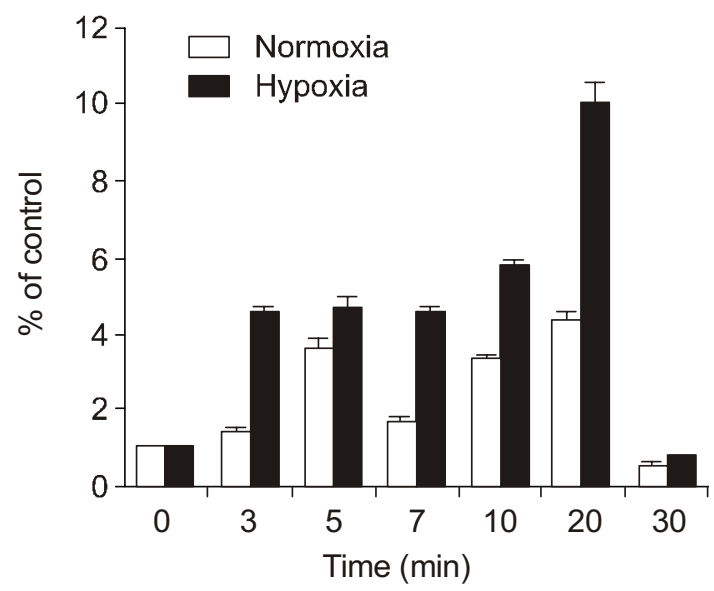

Figure 5. Effect of hypoxia on phosphorylation of p38 kinase activations. Cells were incubated for $48 \mathrm{~h}$ in a serum-free medium and exposed to hypoxia or normoxia for the indicated times. Cell lysates were prepared and proteins were resolved in a $10 \%$ SDSpolyacrylamide gel under reducing condition. p38 kinase activations were analyzed through Western blotting using phospho-p38 kinase antibodies. Data shows a representative figure from three independent experiments and values equal the mean $\pm S E$

A variety of evidence showed that exposure of cells to hypoxia increases the ability to invade the $\mathrm{ECM}$ in vitro and to metastasize in vivo in mouse melanoma, sarcoma and squamous carcinoma cells (Cuvier et al., 1997; Young et al., 1988). Enhanced invasiveness in cells exposed to hypoxia has been reported to be associated with the up-regulation of UPAR in non-malignant trophoblast and endothelial cells (Graham et al., 1993) and MDA-MG-231 breast carcinoma cells (Charles et al., 1999). In the present study, we found that a prostate cancer cell line, PC3MLN4 exhibited a 2-fold higher invasion rate under hypoxic condition than under standard conditions. HGF-mediated invasiveness was also increased in hypoxic cells compared to normoxic cells. Furthermore, hypoxia-mediated invasion decreased with the treatment of an anti-uPAR antibody, mAb 3936. These results suggest that up-regulation of UPAR plays animportant roles in the augmentation of the hypoxiamediated invasiveness in the prostate cancer cells. In an effort to evaluate the possibility that distincit signaling pathways are involved in hypoxia-induced 
A

$\begin{array}{llllll}\text { PD98059 } & - & - & - & + & + \\ \text { Time }(\mathrm{h}) & 0 & 6 & 12 & 6 & 12 \\ \text { UPAR } \rightarrow & \\ \text { GAPDH } \rightarrow & \end{array}$

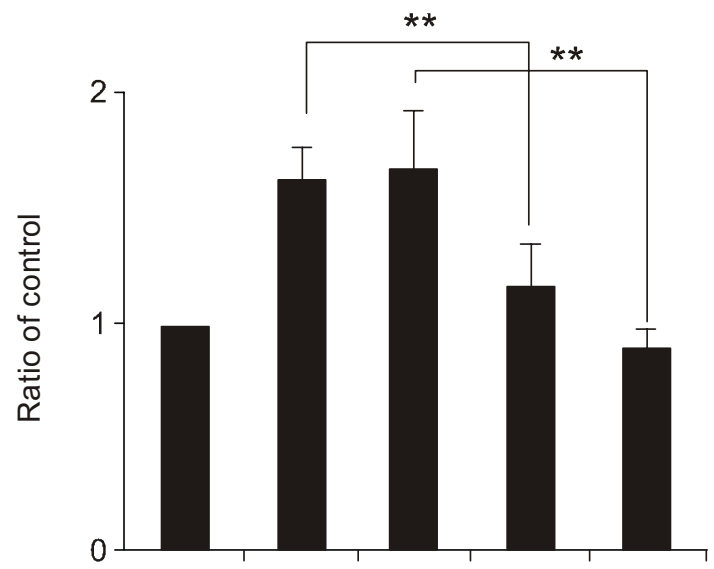

B

$\begin{array}{rrrrrr}\text { SB203580 } & - & - & - & + & + \\ \text { Time (h) } & 0 & 6 & 12 & 6 & 12 \\ \text { uPAR } \rightarrow & \\ \text { GAPDH } \rightarrow & \end{array}$

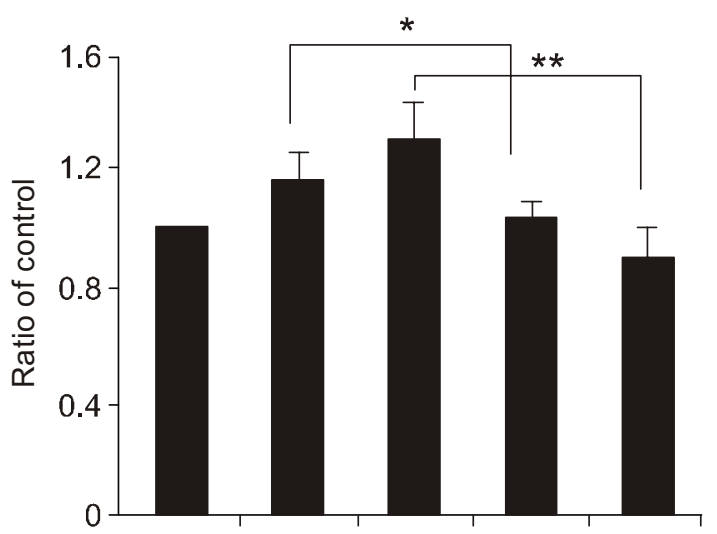

Figure 6. Effect of PD98059 or SB203580 on hypoxia-induced UPAR expression. Serum-starved cells were pretreated with or without $10 \mathrm{mM}$

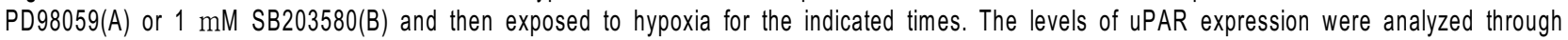
Western blotting using a UPAR antibody. Data shows a representative figure from three independent experiments and values are equal to the mean \pm SE (Statistical analysis: Student's t-test, ${ }^{*} P<0.05$; ${ }^{* *} P<0.01$ compared to the control).

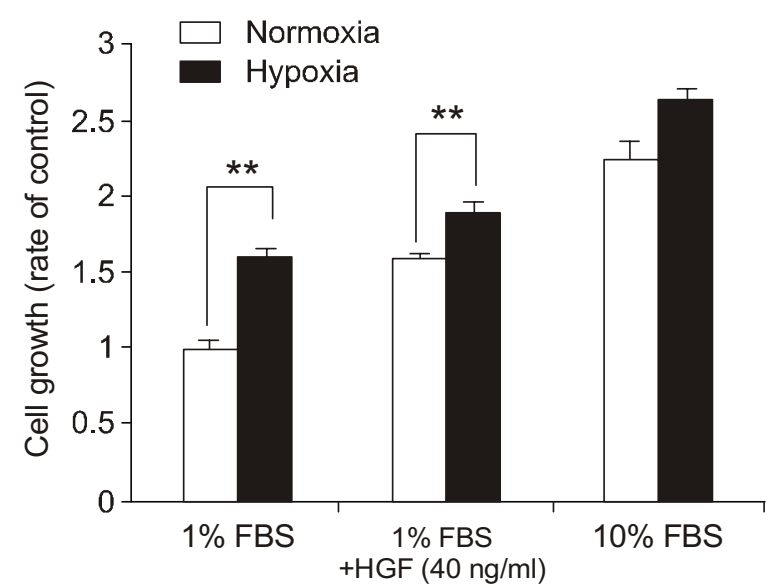

Figure 7. Effect of hypoxia on cell growth. Cells (1000 cell/well) were plated in a 96 well plate with a medium supplemented with $5 \%$ FBS and adhered for $24 \mathrm{~h}$. Cells were serum-starved for $24 \mathrm{~h}$ and treated with $1 \% \mathrm{FBS}, 1 \% \mathrm{FBS}+\mathrm{HGF}(40 \mathrm{ng} / \mathrm{ml})$, and 10\% FBS under hypoxia or normoxia for $72 \mathrm{~h}$. And then viable cells were stained with MTT and resulting formazan crystals were dissolved with DMSO. The absorbance at $570 \mathrm{~nm}$ was measured with a BioRad multiscan plate reader. Values are equal to the mean $\pm S D$ of triplicates of three independent experiments. (Statistical analysis: Student's t-test, ${ }^{* *} P<$ 0.01 compared to the control).
UPAR up-regulation, we measured the phosphorylation of MAP kinases, including ERK and p38. Mita et al (Mita et al., 2001) reported that hypoxia caused early, transient and higher extent activation of ERK and p38 phosphorylation. It is similar to our data. Furthermore, Hypoxia-induced uPAR upregulation was decreased by the pretreatment of PD98059 and SB203580. These results suggest that ERK and p38 kinase activations are involved in the hypxia-mediated UPAR upregulation.

Hypoxia-inducible factor-1 (HIF-1) controls the expression of a number of genes such as vascular endothelial growth factor (Akrit et al., 2000) and UPAR (Krishnamachary et al., 2003). Davren et al (Darren et al., 1999) showed that the activation of the ERK pathway in quiescent cells induced the phosphorylation and activation of HIF-1, which was abrogated in presence of the MEK inhibitor, PD98059. In addition to ERK activation, endogenous p38 MAP kinase activity correlates well with the invasiveness of breast carcinoma cells (Shuang et al., 2000). Treatment of highly invasive BT549 breast cancer cells with a specific p38 MAPK inhibitor, SB203580, diminished both UPA/UPAR mRNA and protein expression, and abrogated the ability of these cells to invade matrigel, suggesting that p38 MAP kinase signaling pathway is involved in the regulation of UPA/UPAR expression 
and invasion in the breast cancer cell.

Hypoxia has been shown to act as a proliferative stimulus for adventitial fibroblast of the pulmonary artery (Das et al., 2001). To evaluate the possibility that hypoxia itself acts as growth-promoting stimulus for PC3MLN4 in the absence of exogenous mitogen, growth-arrested cells, by serum deprivation, were exposed to hypoxia and cell growth was measured. We found that exposure of cells to hypoxia caused an increase in cell proliferation in the presence or absence of HGF compared to normoxic cells.

In summary, we have shown that hypoxia increases tumor cell invasion by up-regulating UPAR expression, which might be mediated through ERK and p38 kinase signaling pathway in the prostate cancer cell line. Our results provide additional supports to the rationale for manipulating oxygen levels in tumor cells and also support the hypothesis that proteolysis of extracellular matrix components by UPA-UPAR complex may be a critical step in tumor invasion and cell death.

\section{Acknowledgement}

This work was supported by a grant from Yeungnam University Medical Center (2002).

\section{References}

Akrit S, Silvia M, Vyomesh P, Muriel Z, Carlos B, Enrique A. The kaposi's sarcoma-associated herpes virus $G$ protein-coupled receptor up-regulates vascular endothelial growth factor expression and secretion through mitogen- activated protein kinase and p38 pathways acting on hypoxiainducible factor 1a. Cancer Res 2000;60:4873-80

Birchmeier C, Birchmeier W. Molecular aspects of mesenchymal-epithelial interactions. Annu Rev Cell Biol 1993;9: $511-40$

Blasi F, Vassalli D, Dano K. Urokinse-type plasmonogen activator. pro-enzyme, receptor, and inhibitors. J Cell Biol 1987; 104:801-4

Body D. Examination of the effects of epidermal growth factor on the production of urokinase and expression of the plasminogen activator receptor in a human colon cancer cell line. Cancer Res 1989;49:2427-34

Brizel DM, Scully SP, Harrelson JM, Layfield LJ, Bean JM, Prosnitz LR, Dewhirst MW. Tumor oxygenation predicts for the likelihood of distant metastases in human soft tissue sarcoma. Cancer Res 1996;56:941-7

Camiolo SM, Markus G, Evers JL. Plasmonogen activator content of neoplastic and benign human prostate tissues; fibrin augmentation of an activator activity. Int $\mathrm{J}$ Cancer 1981;27:191-8

Cantero D, Friess H, Deflorin J, Zinnermann A, Riesle E. Enhanced expression of urokinase plasminogen activator and it's receptor in pancreatic carcinoma. Br J Cancer 1997;75:
388-95

Charles HG, Tania EF, Keith RM. Hypoxia stimulates urokinase receptor expression through a heme protein-dependent pathway. Blood 1998;91:3300-7

Charles HG, Jennifer F, Carolyn JF, Shannyn MG. Hypoxia-mediated stimulation of carcinoma cell invasiveness via upregulation of urokinase receptor expression. Int $\mathrm{J}$ Cancer 1999; 80:617-23

Cobb MH, Goldsmith EJ. How MAP kinases are regulated. J Biol Chem 1995;14843-6

Cuvier C, Jang A, Hill RP. Exposure to hypoxia, glucose starvation and acidosis; effect on invasive capacity of murine tumor cells and correlation with cathepsin $(L+B)$ secretion. Clin Exp Metastasis 1997;15:19-25

Dano K, Andreasen PA, Grondahl-Hansen JJ, Kristensen P, Nielsen LS, Skriver L. Plasminogen activators, tissue degradation and cancer. Adv Cancer Res 1985;44:139-266

Darren ER, Edurne B, Emmanuel G, Daniele R, Jacques $P$. p42/p44 Mitogen-activated Protein Kinases Phosphorylate Hypoxia-inducible Factor 1 (HIF-1) and Enhance the Transcriptional Activity of HIF-1. J Biol Chem 1999;274:32631-7

Das M, Bouchey DM, Moore MJ, Hopkins DC, Nemenoff RA, Stenmark KR. Hypoxia-induced proliferative response of vascular adventitial fibroblasts is dependent on g protein- mediated activation of mitogen-activated protein kinases. J Biol Chem 2001;276:15631-40

De bruin PAF, Griffioen G, Verspaget HW, Vereijen JH, Dooijewaard G, van den Ingh HF, Lamers CB. Plasminogen activator profiles in neoplastic tissues of the human colon. Cancer Res 1988;48:4520-4

Graham CH, Hawley TS, Hawley RG, MacDougall JR. Establishment and characterizaton of first trimester human trophoblast cells with extended lifespan. Exp Cell Res 1993;204: 206-12

Graham CH, Fitzpatrick TE, McCrae KR. Hypoxia stimulates urokinase receptor expression through a heme protein-dependent pathway. Blood 1998;3300-7

Kim KS, Hong YK, Lee Y, Shin JY, Chang SI, Chung SI, Joe YA. Differential inhibition of endothelial cell proliferation and migration by urokinase subdomains amino-terminal fragment and kringle domain. Exp Mol Med 2003;35:578-85

Krishnamachary B, Berg-Dixon S, Kelly B, Agani F, Feldser D, Ferreira G, lyer N, LaRusch J, Pak B, Taghavi P, Semenza GL. Regulation of colon carcinoma cell invasion by hypoxia inducible factor 1. Cancer Res 2003;63:1138-43

Markus G, Takita H, Camiolo S, Corasanti J. Content and characterization of plasminogen activators in human lung tumors and normal lung tissue. Cancer Res 1980;40:841-8

Mita D, David MB, Marla JM, Daniel CH, Raphael AN, Kurt RS. Hypoxia-induced proliferative response of vascular adventitial fibroblasts is dependent on $\mathrm{G}$ protein-mediated activation of mitogen-activated protein kinase. J Biol Chem 2001; 276:15631-40

Nordsmark M, Hoyer M, Keller J, Nielsen OS, Jensen OM, Overgaard J. The relationship between tumor oxygenation and cell proliferation in human soft tissue sarcomas. Int $\mathrm{J}$ 
Radiat Oncol Biol Phys 1996;35:701-9

Ossowsky L. In vivo invasion of modified chorioallantoic membrane by tumor cells: the role of cell surface bound urokinase. J Cell Biol 1988;107:2437-45

Ossowski L, Clunie G, Masucci MT, Blasi F. In vivo paracrine interaction between urokinase and its receptor: effect on tumor cell invasion. J Cell Biol 1991;115:1107-12

Sappino A, Busso N, Belin D, Vassalli J. Increase of urokinase-type plasminogen activator gene expression in human lung and breast carcinoma. Cancer Res 1987;47:4043-6

Seko Y, Tobe K, Ueki K, Kadowaki T, Tazaki Y. Hypoxia and hypoxia/reoxygenation activate Src family tyrosine kinases and p21ras in cultured rat cardiac myocytes. Circ Res $1996 ; 78: 82-90$
Seko Y, Takahashi N, Tobe K, Kadowaki T, Yazaki Y. Hypoxia and hypoxia/reoxygenation activate p65PAK, p38 mitogen-activated protein kinase (MAPK), and stress-activated protein kinase (SAPK) in cultured rat cardiac myocytes. Biochem Biophys Res Commun 1997;239:840-4

Shuang $H$, Liguo $N$, Zhixing $P$, Jiahuai $H$, Glen R. Urokinase plasminogen activator/urokinase surface receptor expression and matrix invasion by breast cancer cells requires constitytive p38 mitogen-activated protein kinase activity. J Biol Chem 2000;275:12266-72

Young SD, Marshall RS, Hill PR. Hypoxia induces DNA overreplication and enhances metastatic potential of murine tumor cells. Proc Nat Acad Sci USA 1988;85:9533-7 